\title{
Editorial:
}

\section{Academic Identities as Epicentres for Social Cohesiveness in Higher Education}

\author{
Daisy Pillay \\ ORCID iD: https://orcid.org/0000-0001-7152-3974
}

Theresa Chisanga

ORCID iD: https://orcid.org/0000-0001-9213-6754

\author{
Anita Hiralaal \\ ORCID iD: https://orcid.org/0000-0003-4364-4327
}

Lungile Masinga

ORCID iD: https://orcid.org/0000-0002-1079-0806

Inbanathan Naicker

ORCID iD: https://orcid.org/0000-0003-2092-0878

\section{Kathleen Pithouse-Morgan \\ ORCID iD: https://orcid.org/0000-0001-8858-8213}

Social cohesion is a contested term and has multiple meanings across disciplinary boundaries (Bruhn 2009). Nonetheless, social cohesion is fundamentally about the quality of human relationships. It is often metaphorically referred to as the glue that holds people together (Capshaw 2005). Social cohesion encompasses 'building shared values and communities of interpretation ... generally enabling people to have a sense that they are engaged in a common enterprise, facing shared challenges, and are members of the same community' (Maxwell 1998:ix). 
Daisy Pillay et al.

As a historical consequence of the traumatising colonial and apartheid regimes, South Africa is burdened with a legacy of social fragmentation, marginalisation, exclusion and inequality. Consequently, pervasive social separateness and discrimination persist in the contemporary South African higher education landscape (Soudien et al. 2008) circumscribed within a neoliberal corporate managerialist agenda. Higher education institutions 'can act to increase social cohesion, or they can act in ways that exacerbate the cleavages of class, race, religion, national origin, and culture, hence pulling society apart' (Capshaw 2005:53). Sadly, the latter appears to be more prevalent in South Africa, as noted in the report by the Ministerial Committee on Transformation and Social Cohesion and the Elimination of Discrimination in Public Higher Education Institutions (Soudien et al. 2008), and the subsequent response from the Council on Higher Education [CHE] (2009).

Social cohesion has been identified as a national priority for South African higher education (CHE 2013). Higher education institutions are expected to 'effect social cohesion by promoting the culture of academic integrity [through] facilitating a sense of community ... and by creating a diverse environment' (Moiseyenko 2005:94). Academics within higher education institutions are tasked with fostering social cohesion by cultivating mutually benefitting connections between people with diverse histories and positionings. Thus, studying the intersections between an evolving understanding of social cohesion and academic identities is a priority for higher education research in contemporary South Africa, as it is elsewhere for academics committed to taking up critical and contested issues of self and social change for a greater public good.

Many studies on academics' everyday lives in higher education settings are from a macro and structural perspective, and their views and practices are often represented quantitatively (Hernández et al. 2010). As powerful as the statistics might be, these need to be complemented by complex narratives that reveal the 'intersecting messiness' of the lived experiences of academics who traverse the 'in/visible borderlands of Higher Education' (Belluigi et al. 2019:5). Narratives can provide essential insights into how academics in higher education can (or cannot) renegotiate their identities and values as moments of possibility and hope for the disruption of social and historical hierarchies and divides.

This themed issue of Alternation explores how and why academics from multiple knowledge fields in South Africa and the United States of 
America (USA) position themselves vis-à-vis social cohesion in their everyday lives and educational practices. The articles highlight diverse, innovative modes and lenses for representing, interpreting, and theorising academics' lived experiences in response to pressing social cohesion-related challenges and dilemmas in higher education. Drawing on a range of research approaches, methods and data sources, the authors generate new and differ-rent knowledge on social cohesion and academic identities. Collectively, this issue opens up conversations about the possibilities and intricacies of facilitating complex, contradictory, and multiple understandings of social cohesiveness and academic selves.

The issue opens with three black early career academics, Nosipho Mbatha, Vusi Msiza and Nokukhanya Ndlovu. Their article, 'Redefining our Identities through Social Cohesion: A Poetic Inquiry of Early Career Academics in a Teacher Education Institution', shares their experiences as staff development fellows in a South African institution dominated by pre-1994 systemic structures. The study explores how they navigate what they perceive as a traditionally hostile environment as young people of colour. They begin by identifying their challenges as 'outsiders' who see themselves as novices with little publishing experience and who lack confidence and often feel unwelcome in their positions. They give an outline of some of their experiences and how they went about reclaiming their space. Drawing upon identity work, they share how they worked to find their voices through critical friendship and co-constructed a more socially cohesive environment for themselves. In the process, they managed to establish what they call their 'authentic selves'. Using intersectionality and poetic inquiry, the paper deals tacitly with racial issues and gender and patriarchal subjugation, among others, not uncommon in a country still to transform from its past by being more inclusive.

The authors of the second article, Grant Andrews and Henry Nichols, are South African lecturers with a shared research interest in gender and sexuality studies. Their study, 'Developing Academic Identities as Gay Lecturers at South African Universities: Two Autoethnographic Narratives', explores the question, 'How are the academic identities of the two participating gay male lecturers developed in relation to educational and professional experiences?' They used autoethnographic reflection, generating data through conversation and personal narrative reflections. Queer theory and theories of masculinities frame their work. According to 
the authors, supportive queer mentors and peers and a concern for social justice and social cohesion were significant factors in developing their academic identities. The article considers social cohesion as an encompassing mechanism that allows queer people to feel included in educational and academic spaces and feel safe and free to be themselves both within particular groups and their broader institutions. Therefore, the autoethnographic reflections presented in their article contribute to understanding academic identities and social cohesion for queer people in South African educational spaces. The authors emphasise how continued educational reform and institutional change could lead to greater belonging.

In "“Why Does This Make Me So Angry?": Using Self-Study to Uncover Hidden Epistemological Frames for Academic Identity Development', Brianne Morettini and Kathryn Luet use their lived experiences as associate professors in the USA to examine social cohesion and their evolving academic identities. Sensemaking theory and poststructural feminism frame their exploration as two critical friends. Engaged in intimate scholarship, they explore their post-tenure experiences of resisting patriarchal institutional norms subjugating women to service roles. They initially set out to do this work, in part, to increase their social cohesion with each other, thereby enabling a greater sense of belongingness in their institution. However, this study made them aware that their emotional responses to their experiences changed and modified their professional identities. Thus, they conclude that emotionally engaged research provides a fertile ground to explore social cohesion in higher education because it reveals aspects of the female self subordinated by patriarchal institutional norms.

\section{'Legitimate Generators of Knowledge: Developing Teacher and Teacher Educator Identity through Participation in Collaborative Undergraduate Research', is authored by three Clinical Associate Pro-} fessors and faculty members - Sherry Dismuke, Lisa Beymer and A.J. Zenkert - working with two undergraduate teacher candidates (Julianne Mori and Claire Oberg) at a university in the USA. In their collaborative self-study, they reflect on and confront the perceived barriers they experience in developing researcher identities as teacher educators and teacher candidates. From an inquiry-based stance, they position knowledge generating for enhancing undergraduate teaching practice as an active and potential site for empowering teacher educators and teacher candidates as 
researchers of legitimate knowledge. They argue that collaboration, trust, respect, and collective inquiry are essential ingredients for teacher educators and undergraduate candidates in co-constructing researcher identities. According to the authors, self-narratives experienced and told are powerful tools for understanding self as an agent in constructing and reconstructing teacher-researcher identity. They also highlight wrestling with self by summoning the gaze of critical others as an essential dimension for expanding funds of knowledge as researchers. Overall their study shows that cohesive research communities of practice in institutions of higher learning are potent spaces to partner and pursue inquiries to improve the quality of teaching.

The authors of 'Reimagining Madiba's Merc and a "Thank You" Postcard as Objects of Social Cohesion in a South African Higher Education Institution' are academics and a librarian from a rural university in South Africa's Eastern Cape Province. They have varied backgrounds in Political Studies (Gladys Ashu), Consumer Studies Education (Mandisa Dhlula-Moruri), Health Sciences (Mukund Khatry-Chhetry), Library Sciences (Elizabeth Pamela Mavume), English Studies (Lazarus Mulenga), Anthropology (Kholekile Ngqila), and Life Sciences Education (Tholani Tshuma). To answer the question, 'What can we learn about social cohesion in higher education through object inquiry?', their collaborative study uses image-based research and the Reflexive Ubuntu theoretical framework. The late Nelson Mandela's Mercedes Benz (Merc) sedan was analysed as a symbol of societal harmony, as was a 'Thank You' postcard from the Sisters of Santa Chiara. Collaborative object inquiry revealed multiple layers of relevance and a polysemic concept of social cohesiveness in higher education practitioners' professional and everyday lives. Collaboration, cultural change and diversity, leadership, sacrifice, and selflessness were revealed as essential aspects of achieving social cohesion and transformation in higher education. According to the authors, selfexamination and collaborative inquiry are required for higher education practitioners to genuinely improve their personal and professional capacities and thinking to contribute to institutional transformation and social cohesion projects. They also argue that collaborating and sharing expertise and resources inside and across universities are critical for a more socially equitable and cohesive South African higher education system. The authors remind us that institutions of higher learning should serve as epicentres for 
social cohesiveness, which can spread to other groups, communities, and eventually the country.

The authors of 'Transcending Paradigmatic Fractures: Reflections on a Critically Conscious Academic Identity through a Decolonial Lens' are a collective of mid-career to late-career South African academics in science and mathematics education. Ronicka Mudaly, Vimolan Mudaly, Nonhlanhla Mthiyane, and Doris Sibanda explore their negotiation of the demands of higher education institutions in South Africa and the call by students to decolonise curricula. They note that mathematics and science curricula are grounded mainly in Euro-western paradigms, contributing to social fragmentation. Drawing on storyboarding and reflective practice in their narrative inquiry, they examine their role in making mathematics and science education inclusive of African epistemologies. By transforming academic selves from corporate agents to social actors, they illustrate how to transcend taken-for-granted boundaries of thinking and doing.

"Feminist Decoloniality as Care": Alternate Paths to Supporting Black Women's Academic Identities and Fostering Critical Social Cohesion' is written by South African researchers Ingrid Bamberg, Ronelle Carolissen, Saajidha Sader, and Relebohile Moletsane, who hail from diverse backgrounds. Against a gendered, corporate managerialist higher education setting that tends to undermine the contribution of women in research, teaching, community engagement, and leadership, the study explores neoliberallism, gender, and curricula at three South African universities. Drawing on data generated from a collaborative research project that employs participatory methodologies, the study uses a philosophical framework, 'feminist decoloniality as care', to theorise its findings. The article contributes to social cohesion scholarship by illustrating how creative feminist participatory methodologies enable repositioning of self and fostering a community practice that challenges prevalent university discourse.

The final article, 'Towards a Counter-Narrative: Why Dissent/ Agonism Might Have Appeal in a Neoliberal Higher Education Space!', is authored by a group of racially and linguistically diverse middle to latecareer professors and academics across a range of South African higher education settings. Drawing on the notion of an antagonistic logic, they critically reflect on, contest, and interrogate their morphing academic identities to challenge liberal, ideological ideas of social cohesion promoting selfabsorbed, neoliberal pursuits. Each author offers individual personal 
narratives as counter-intuitive explorations provoked by the question of the potentiality of dissent in a neoliberal, global, and capitalist higher education assemblage. As a deliberate, ethical act, rhizomatic dissent offers an evolving and open understanding of social cohesion aligned with a complex and diverse society. The authors remind us that social cohesion understood as a deliberate assemblage of dialogic, oppositional relationships, can generate a commitment to a mutually beneficial lifelong affair of experimentation. They argue that institutions of higher learning should serve as sites for disrupting social cohesion as a hegemonic, harmonious narrative imposed from the top. The six authors are, Suriamurthee Moonsamy Maistry, Sylvan Blignaut, Petro Du Preez, Lesley Le Grange, Labby Ramrathan, and Shan Simmonds. And, they propose that social cohesion should be experienced as a productive agonistic deliberative, constructed from below.

Taken as a whole, this themed Alternation issue illustrates the significance of researching narratives of lived experience for contesting, reconsidering, dialoguing, and playing with notions of academic identities and social cohesion for the greater public good. The articles in the issue highlight the complexity and multiplicity of human experiences, interactions, and feelings that give life and meaning to academic identities and social cohesion in higher education institutions as evolving, lifelong experimentation.

To close, we offer a pantoum poem, Epicentres for Social Cohesiveness, created from an overview of each article's critical contributions. We chose the French Malaysian pantoum format with 'its repetitive lines [because] the repetition of salient or emotionally evocative [ideas]' (Furman, Lietz \& Langer 2006:28) identify and communicate the composite contribution of this themed issue.

\section{Epicentres for Social Cohesiveness}

Lifelong affair of experimentation

To transform from its past

Often vulnerable, feelings of belonging,

Emotionally engaged research

To transform from its past.

Repositioning self, fostering community practice

Emotionally engaged research

Epicentres for social cohesiveness 
Daisy Pillay et al.

Repositioning self, fostering community practice

Often vulnerable, feelings of belonging

Epicentres for social cohesiveness

Lifelong affair of experimentation

Epicentres for Social Cohesiveness shows how understanding academics' lived experiences concerning social cohesion calls for self-repositioning, nurturing community, and being open to dissent, learning, and growth. Through emotionally engaged innovative research, we can create epicentres for social cohesiveness.

\section{Acknowledgement}

The editors of this themed issue of Alternation, gratefully acknowledge grant funding from the National Research Foundation (NRF) of South Africa (Human and Social Dynamics in Development Grant Number 118539). We further acknowledge that any opinions, findings and conclusions or recommendations expressed in this material are those of the authors and therefore the funders do not accept any liability in that respect.

\section{References}

Belluigi, D.Z., A. Alcock, V. Farrell \& G. Idahosa 2019. Mixed Metaphors, Mixed Messages and Mixed Blessings: How Figurative Imagery Opens up the Complexities of Transforming Higher Education. Scholarship of Teaching and Learning in the South 3,2: 110 - 120. https://doi.org/10.36615/sotls.v3i2.105

Bruhn, J.G. 2009. The Group Effect: Social Cohesion and Health Outcomes. Dordrecht, Heidelberg, London \& New York: Springer.

https://doi.org/10.1007/978-1-4419-0364-8

Capshaw, N.C. 2005. The Social Cohesion Role of the Public Sector. Peabody Journal of Education 80,4: 53 - 77.

https://doi.org/10.1207/S15327930pje8004 5

Council on Higher Education [CHE] December 2009. The Response of the Council on Higher Education to the Report of the Ministerial Committee on Transformation and Social Cohesion and the Elimination of Discrimination in Public Higher Education Institutions. Pretoria: Council on Higher Education. 
Council on Higher Education [CHE] August 2013. A Proposal for Undergraduate Curriculum Reform in South Africa: The Case for a Flexible Curriculum Structure. Report of the Task Team on Undergraduate Curriculum Structure. Pretoria: Council on Higher Education.

Furman, R., C.A. Lietz \& C.L. Langer 2006. The Research Poem in International Social Work: Innovations in Qualitative Methodology. International Journal of Qualitative Methods 5,3: 24 - 34.

https://doi.org/10.1177/160940690600500305

Hernández, F., J.M. Sancho, A. Creus \& A. Montané 2010. Becoming University Scholars: Inside Professional Autoethnographies. Journal of Research Practice 6,1: Art. M7.

http://jrp.icaap.org/index.php/jrp/article/view/204/188

Maxwell, J. 1998. Foreword. In Jenson, J. (ed.): Mapping Social Cohesion:

The State of Canadian Research. Ottawa, Canada: Canadian Policy Research Networks Inc.

Moiseyenko, O. 2005. Education and Social Cohesion: Higher Education. Peabody Journal of Education 80,4: 89 - 104.

https://doi.org/10.1207/S15327930pje8004 7

Soudien, C., W. Michaels, S. Mthembi-Mahanyele, M. Nkomo, G. Nyanda, N. Nyoka, S. Seepe, O. Shisana \& C. Villa-Vicencio November 2008. Report of the Ministerial Committee on Transformation and Social Cohesion and the Elimination of Discrimination in Public Higher Education Institutions. Pretoria: Department of Education.

\section{Daisy Pillay University of KwaZulu-Natal Pillaygv@ukzn.ac.za}

Theresa Chisanga Walter Sisulu University tchisanga@wsu.ac.za

Anita Hiralaal Durban University of Technology anitah@dut.ac.za 
Daisy Pillay et al.

Lungile Masinga

University of KwaZulu-Natal

Masingal@ukzn.ac.za

Inbanathan Naicker

University of KwaZulu-Natal

Naickeri1@ukzn.ac.za

Kathleen Pithouse-Morgan University of KwaZulu-Natal Pithousemorgan@ukzn.ac.za 